REVISTA NOMADÍAS

Julio 2011, Número Nº 13, 153 - 155

\title{
Caminos y cambios en distintos lugares del mundo
}

\author{
Enrique Antileo \\ Universidad de Chile \\ enrique.antileo@gmail.com
}

Se presenta ante mis ojos información de las movilizaciones acaecidas en Egipto y Túnez recientemente. No deja de sorprenderme la masividad de estos movimientos que han sacado a las calles su indignación. En particular, leo con atención la obra de ciertas mujeres en el contexto general de estas sociedades y en el momento específico de las manifestaciones, así como el papel que han jugado en ellas. A medida que avanza mi lectura, sólo me queda intentar responder qué pienso, desde mi lugar (joven mapuche nacido en la diáspora), sobre el activismo político, sobre el espacio de las mujeres y sobre las transformaciones que veo en mis pocos años de historia.

Es evidente la conmoción que cada cierto tiempo -quién lo negaría- provocan aquellas imágenes difundidas por los medios de comunicación de masas acerca del mundo árabe, donde vemos cómo muchos hombres maltratan mujeres con todo el amparo de la institucionalidad. Por supuesto que también trato de hacer el ejercicio de identificar el lugar desde donde relatan esos medios, de visualizar su occidentalismo acérrimo y su ánimo de continuar presentando al mundo dividido entre civilización y barbarie, desde una posición unilateralmente universal.

Aún en este escenario lleno de imágenes que intencionalmente circulan en los mass media pretendiendo denostar al mundo árabe, debo reconocer que me alegro de poder acceder a información alternativa y observar los avances del día a día en las calles y también del empoderamiento de las mujeres en las luchas de los pueblos y su activo rol opinante y transformador. Mi alegría no se debe a la supuesta asimilación del modelo de la sociedad occidental que promueve la liberación de la mujer, como muchos pretenden justificar; tengo en cuenta que lo anterior no es tal, asumiendo que en dichas sociedades las mujeres fueron hasta hace muy poco, y lo siguen siendo hoy en día, marginadas. 
Me alegro más bien porque, como dijera Héctor Díaz Polanco, la sociedad humana es una formidable maquinaria que fabrica incesantemente diversidad cultural, por lo tanto, visualizo que siempre pueden existir transformaciones en prácticas culturales, sociales y políticas atingentes a la mujeres. Y en este último sentido, me alegro mucho más porque dichas aperturas nos permiten tratar uno de los grandes problemas de las luchas que nos mueven y nos conmueven: ser cada día más y que cada uno de nosotros se sienta parte, que los hombres no somos dueños ni representantes exclusivos de las luchas y que con el aporte de las mujeres estaremos sin duda construyendo un mundo mejor.

No puedo evitar entonces mirar también a mi pueblo, al movimiento en que participo y ver también como las mujeres paulatinamente ganan sus espacios de visibilización y participación política. Es claro que nuestra sociedad no es la misma de antes y me llena de esperanza que en relación a este aspecto específico no lo sea, pues de este modo estamos logrando caminar juntos, wentru ka domo (hombres y mujeres), de igual a igual en esta lucha y en todas las luchas donde nos comprometemos.

De todas maneras es importante distinguir algunas cosas. Reconozco, y por lo menos esa es mi postura, que la sociedad mapuche ha padecido de los mismos síntomas de machismo y violencia de género que otras sociedades en el orbe. No tengo la certeza ni la datación de esas prácticas, que podrían venir de mucho tiempo o también ser parte de un colonialismo internalizado a lo Silvia Rivera Cusicanqui. Lo importante es admitir que esas posturas ciegas, esencialistas, que en base a una utilización acomodaticia de la dualidad o de la complementariedad pretenden seguir perpetuando la subalternización de la mujer, no contribuyen a generar movimientos ampliamente participativos ni sociedades más justas.

A veces al mirarnos, al observar nuestras luchas, hallamos discursos y formas de actuar que caen en lo mítico, en la búsqueda de una pureza o de pueblos perfectos. Esas vanidades colectivas muchas veces no permiten comprender que existen procesos de transformación, que las culturas cambian conforme pasa el tiempo, que los pueblos mutan y se interrelacionan constantemente con otros, que lo pasado no es necesariamente lo mejor, que el presente nos da muchas cosas para pensar y que el futuro es el territorio al que debemos aspirar.

Al leer sobre cineastas egipcias que alzan su voz, activistas del Medio Oriente, escritoras libanesas o mujeres de origen árabe que porfían en Europa por llevar sus indumentarias, pienso en 
las dimensiones de esas luchas y como se van rompiendo cercos diferentes. Me obligo también a mirar a mi familia, a mi organización, a mi movimiento y ver la manera en que, con el paso del tiempo, las mujeres han ido tejiendo espacios valiosísimos, siendo capaces de posicionar su voz en estas tareas colectivas. Y sin querer martirizar a algunas, desmerecer a otras ni olvidar a las que anónimamente han generado cambios importantes, pienso a propósito de estas divagaciones en Patricia Troncoso, activista mapuche siempre altiva que fue condenada por el Estado chileno a diez años de prisión por la lucha de liberación de su pueblo; pienso en las madres, esposas e hijas de los cientos de prisioneros mapuche que han debido reconstruir sus vidas en medio de la represión; y pienso en Mireya Figueroa, hermosa mujer que ha muerto hace poco tiempo a causa de un cáncer, quien vivió por años la clandestinidad y parte de su último tiempo en la cárcel. A ellas esta humilde columna. 